\title{
Garbage in, garbage out
}

\section{À données inexactes, résultats erronés}

$\mathrm{I}$ $\mathrm{n}$ the current issue of the Canadian Respiratory Journal, Spurr et al (1) (pages 213-218) examined hospital discharge data regarding obstructive sleep apnea (OSA), with essentially noncredible results. Using the Canadian Institute for Health Information (CIHI) Discharge Abstract Database (CIHI-DAD) records for 2006/2007, they examined the prevalence and clinical characteristics of patients diagnosed with OSA. Their findings were to state it mildly - surprising. The CIHI-DAD apparently offers three diagnostic categories for apnea: OSA, central and 'other', presumably including mixed obstructive and central apneas.

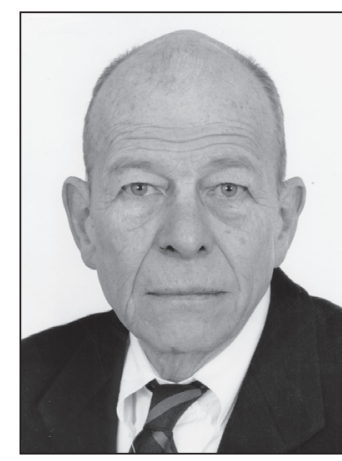

Nick R Anthonisen
Pans le présent numéro de la Revue canadienne de pneumologie, Spurr et coll. (1) (pages 213-218) examinent les données sur les congés hospitaliers liés à l'apnée obstructive du sommeil (AOS), et leurs résultats sont, pour l'essentiel, non crédibles. Au moyen des dossiers de la base de données sur les congés des patients de l'Institut canadien d'information sur la santé (BDCP-ICIS) pour 2006 2007, ils ont examiné la prévalence et les caractéristiques cliniques des patients ayant une AOS diagnostiquée. Leurs observations, c'est le moins qu'on puisse dire, sont surprenantes. La BDCP-ICIS offre apparemment trois catégories diagnostiques d'apnée : l'AOS, l'apnée centrale et une « autre » Spurr et al did not examine records coded for central apnea. The 'other' diagnoses were uncommon - approximately $0.6 \%$ of all patients had either type of apnea, with $57 \%$ being OSA, the remainder being 'other'. Some 25\% of OSA patients were younger than 19 years of age, with most being younger than 10 years of age. Of the adults with OSA, it was the primary diagnosis in approximately one in six, and was associated with the usual comorbidities - hypertension, type 2 diabetes and morbid obesity. In adult patients who were coded with OSA, the most frequent therapeutic interventions were upper airway surgery (nearly 10\%), pressure ventilation via endotracheal tube or tracheostomy and, finally, noninvasive continuous positive airway pressure (CPAP) or bilevel positive airway pressure (BiPAP). Approximately 5\% of OSA patients underwent noninvasive pressure ventilation. The CIHI-DAD dataset did not discriminate between CPAP and BiPAP treatment. Patients treated with ventilatory support experienced longer hospital stays, and were more often discharged to continuing care facilities and less often to home than those who did not receive such support.

What is wrong with this picture? Nearly everything, I think as did the physicians who originally reviewed the paper. OSA is a far more common disease than data indicate, even allowing for the likelihood that hospitalization rates are probably low. OSA is common in older adults and not in children. OSA comprises a larger fraction of sleep apneas than found in these data. Noninvasive CPAP therapy is, by far, the treatment of choice for OSA, with upper airway surgery being a measure of last resort.

There are probably two reasons for this misrepresentation of apneas: poor specificity of coding choices available in the CIHI-DAD, and inaccurate coding by the doctors and hospitals involved. The CIHI-DAD offers three diagnoses for sleep apnea: obstructive, central and 'other'. The Canadian Thoracic Society guidelines (2) for sleep-disordered breathing clearly identify four diagnostic categories: obstructive apnea/hypopnea, central apnea/hypopnea, Cheyne-Stokes breathing and hypoventilation. Data contained in the CIHI-DAD do not differentiate CPAP from BiPAP therpies, yet these treatments are often applied to different patients, with BiPAP used as an apnée, incluant probablement un mélange d'apnée obstructive et d'apnée centrale. Spurr et coll. n’ont pas examiné les dossiers codés de l'apnée centrale. Les « autres » diagnostics étaient peu courants - environ 0,06 \% de tous les patients avaient les deux types d'apnée, $57 \%$ une AOS, et le reste, une « autre » apnée. Quelque $25 \%$ des patients ayant une AOS avaient moins de 19 ans, et la plupart, moins de dix ans. Chez les adultes ayant une AOS, c'était le diagnostic primaire dans environ un cas sur six, et il s'associait aux comorbidités habituelles : hypertension, diabète de type 2 et obésité morbide. Chez les patients adultes ayant un code d'AOS, les interventions thérapeutiques les plus fréquentes étaient une opération des voies respiratoires supérieures (près de $10 \%$ ), une ventilation en pression positive par sonde trachéale ou trachéotomie et, enfin, une pression positive continue (PPC) non effractive ou une pression positive expiratoire $(\mathrm{PPEDN})$ à deux niveaux. Environ $5 \%$ des patients ayant une AOS ont subi une ventilation en pression positive non effractive. L'ensemble des données de la BDCP-ICIS ne faisait pas de distinction entre le traitement par PPC ou par PPEDN. Les patients traités par soutien ventilatoire étaient hospitalisés plus longtemps, étaient davantage transférés dans un établissement de soins de longue durée et obtenaient moins souvent leur congé à domicile que ceux qui ne recevaient pas de soutien.

Qu'est-ce qui cloche dans ce portrait ? Pratiquement tout, je pense, à l'instar des médecins qui ont révisé l'article au départ. L'AOS est une maladie beaucoup plus courante que ce qu'indiquent les données, même si on tient compte de la probabilité de faibles taux d'hospitalisation. L'AOS est courante chez les adultes âgés, mais pas chez les enfants. L'AOS inclut une fraction plus importante de troubles du sommeil que ce que laissent voir ces données. La PPC non effractive est, de loin, le traitement de choix de l'AOS, l'opération des voies respiratoires supérieures étant une mesure de dernier recours.

Deux raisons expliquent probablement cette présentation fallacieuse des apnées : la mauvaise spécificité des choix de codes proposés dans la BDCP-ICIS, et un codage inexact de la part des médecins et des hôpitaux. La BDCP-ICIS offre trois diagnostics d'apnée du sommeil : obstructive, centrale et « autre ». 
intensive care intervention in people with disorders of lung mechanics. This, rather than OSA, probably accounts for the relatively common use of invasive ventilation, and the long hospital stay and unpleasant patient outcomes.

It is difficult, however, to blame the CIHI for the apparently low use of noninvasive CPAP therapy in patients diagnosed with OSA. It may be that CPAP is not really used much, or that it is used and simply not noted in the discharge data. While I prefer the latter alternative, there is no evidence supporting it. The high frequency of upper airway surgery probably should not be a surprise because this is the type of event that the CIHI is careful to record. The number of very young people with OSA flummoxes me, but perhaps the sensitivity of these patients' physicians was very high.

Nevertheless, the message from the paper by Spurr et al is that the CIHI-DAD is virtually useless for the study of sleep apnea and, although this is certainly true, we should perhaps be more worried that inpatients with sleep apnea may not be appropriately treated.

\section{REFERENCES}

1. Spurr KF, Morrison DL, Graven MA, Webber A, Gilbert RW. Analysis of hospital discharge data to characterize obstructive sleep apnea and its management in Canada: 2006-2007. Can Respir J 2010;17:213-8.

2. Fleetham J, Ayas N, Bradley D, et al. Canadian Thoracic Society Guidelines: Diagnosis and treatment of sleep-disordered breathing in adults. Can Respir J 2006;13:387-92.
Les lignes directrices de la Société canadienne de thoracologie (2) relatives aux événements respiratoires du sommeil exposent clairement quatre catégories diagnostiques : apnée obstructive et hypopnée, apnée centrale et hypopnée, respiration de Cheyne-Stokes et hypoventilation. Les données contenues dans la BDCP-ICIS ne différencient pas la PPC de la PPEDN, mais ces traitements sont souvent administrés à des patients différents, la PPEDN étant utilisée en soins intensifs chez des personnes ayant des troubles de la mécanique pulmonaire. Selon toute probabilité, ce sont ces constatations, plutôt que l'AOS, qui expliquent l'utilisation relativement courante de la ventilation effractive, la longue durée d'hospitalisation et les issues médiocres des patients.

Il est toutefois difficile de blâmer l'ICIS pour l'utilisation apparemment peu élevée de la PPC non effractive chez les patients ayant un diagnostic d'AOS. Il se peut que la PPC ne soit pas tellement utilisée ou qu'elle le soit sans que les données du congé ne l'indiquent. Je préfère la dernière possibilité, mais aucune donnée ne l'appuie. La forte fréquence d'opérations des voies respiratoires supérieures ne devrait probablement pas être surprenante, puisque c'est le type d'événement que l'ICIS s'assure de consigner. Le nombre de très jeunes personnes ayant une AOS me coupe le sifflet, mais les médecins de ces patients avaient peut-être une très forte sensibilité.

Néanmoins, le message que transmet l'article de Spurr et coll., c'est que la BDCP-ICIS est virtuellement inutile pour étudier l'apnée du sommeil, et bien que cette constatation soit indéniable, nous devrions peut-être nous inquiéter davantage du risque que les patients hospitalisés ayant une apnée du sommeil reçoivent un traitement inopportun.

\section{RÉFÉRENCES}

1. Spurr KF, Morrison DL, Graven MA, Webber A, Gilbert RW. Analysis of hospital discharge data to characterize obstructive sleep apnea and its management in Canada: 2006-2007. Can Respir J 2010;17:213-8.

2. Fleetham J, Ayas N, Bradley D et coll. Canadian Thoracic Society Guidelines: Diagnosis and treatment of sleep-disordered breathing in adults. Can Respir J 2006;13:387-92. 


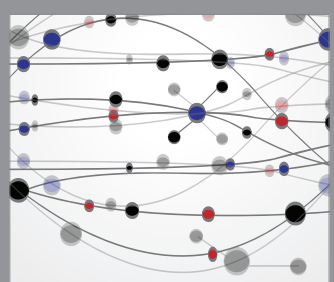

The Scientific World Journal
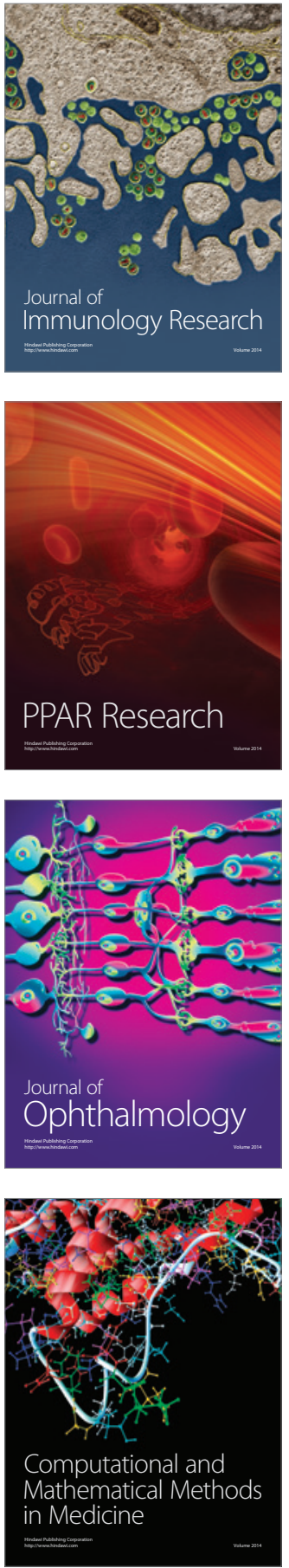

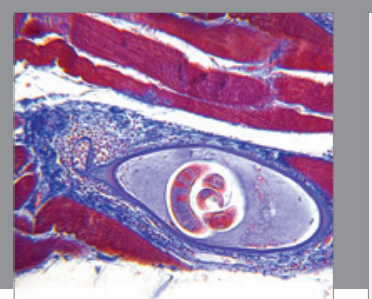

Gastroenterology Research and Practice

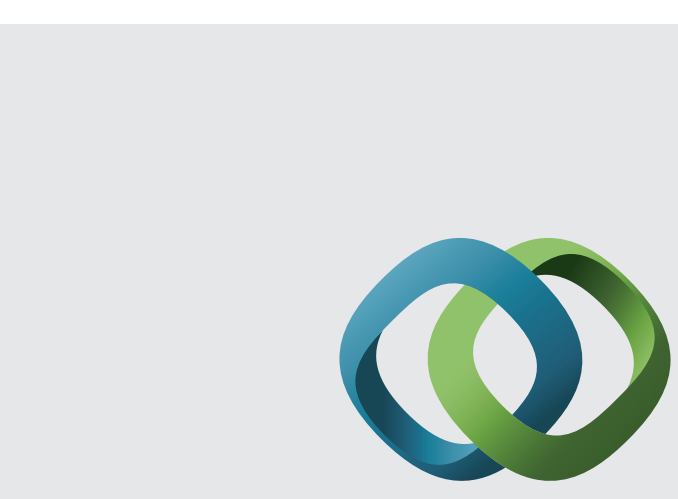

\section{Hindawi}

Submit your manuscripts at

http://www.hindawi.com
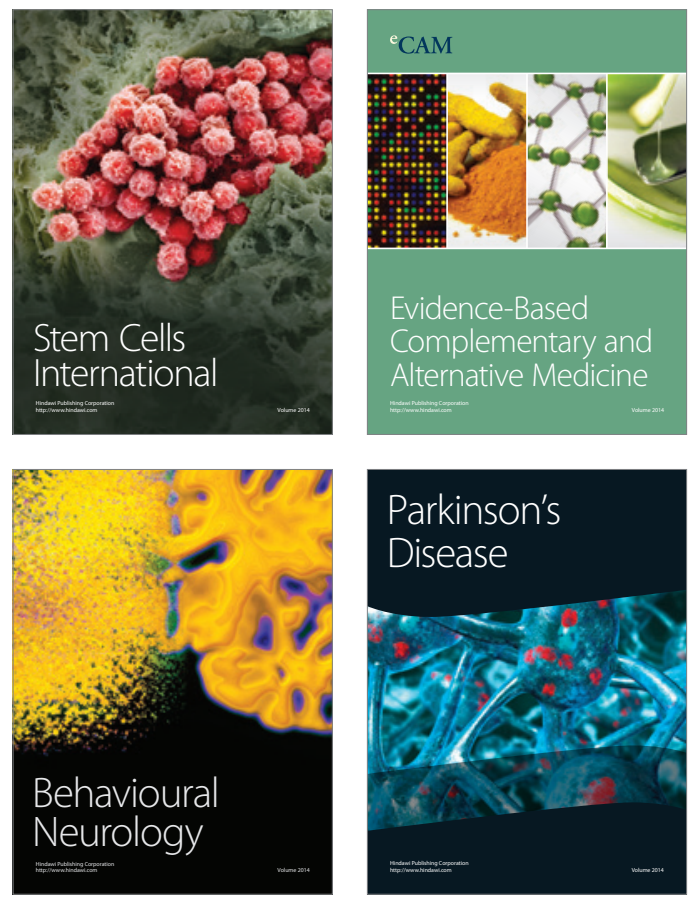
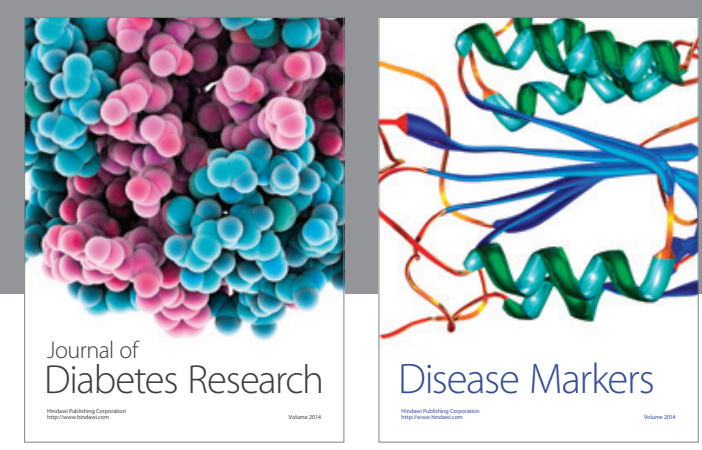

Disease Markers
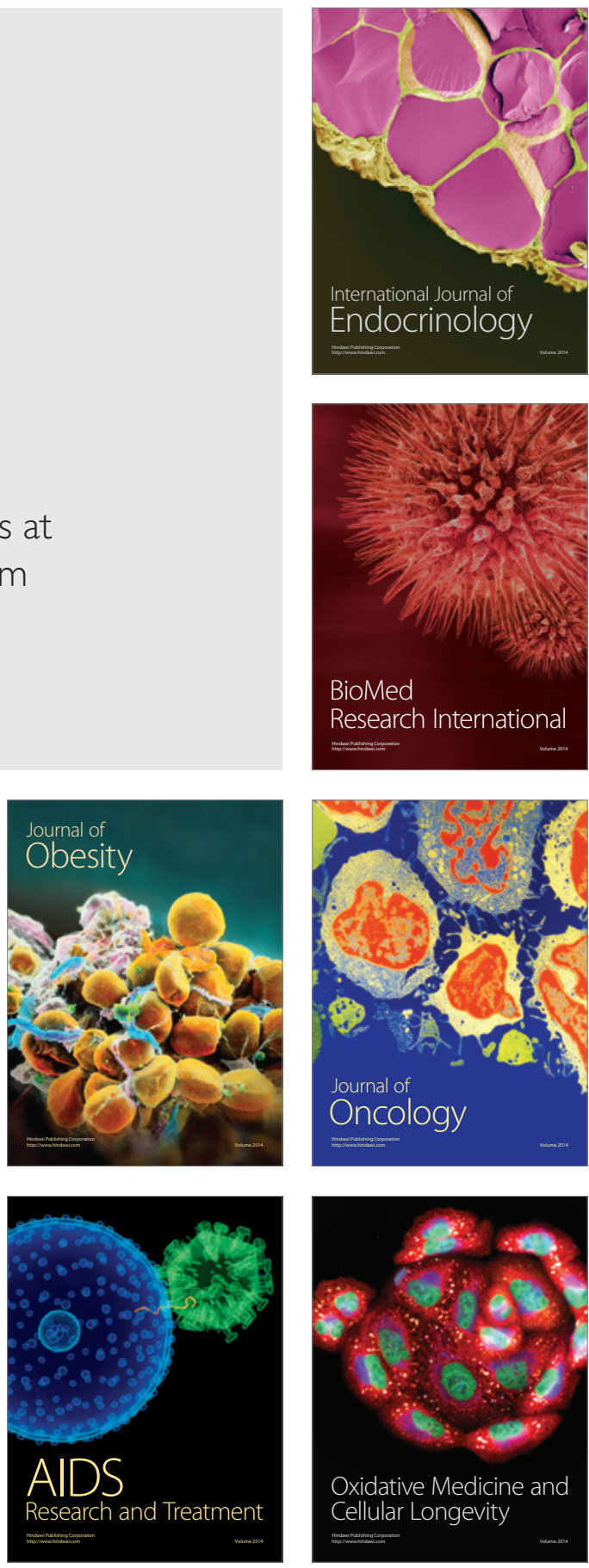